\title{
Exploring public trust in policing at a community in Ghana
}

\author{
Gerald Dapaah Gyamfi ${ }^{1}$
}

Accepted: 29 November 2021 / Published online: 9 January 2022

(c) The Author(s), under exclusive licence to Springer Nature Limited 2021

\begin{abstract}
Public trust in community policing plays a major role in enhancing police effort in securing peace, public safety, and crime combat. Fractured relationship between a community and the police breeds corruption and social disorderliness. This study used qualitative case study to explore public trust in community policing at a periurban community in Ghana using 120 landlords as respondents. The researcher used interview, triangulated with focus group and direct observation, to collect data from the subjects who freely consented to become participants of the study. The author of this paper ensured reliability of the outcome of the study using member-checking, bracketing, and rigor. A qualitative software, NVivo, aided the analysis of the data which generated three main themes. The outcome of the study revealed that lack of public trust in the community policing resulted from fear of reprisals from criminals reported to the police, poor visibility of police officers, and lack of confidence due to perceived poor performance of the police.
\end{abstract}

Keywords Policing in Africa · Police-community relationship - Oyibi community · Reprisals · Ghana Police Service · Police visibility · Qualitative case study

\section{Introduction}

Community policing is a complex security system that involves the people of a community supporting the police in discharging their duties as public servants. It is a police strategy that focuses on working in partnership with residents of a community as a means to involve them in executing their law enforcement duties (Shupard and Kearns 2019). Effective community policing involves understanding of some crucial multi-faceted factors that influence the police officers' behavior in their duty of preventing, detecting, investigating, and apprehension of offenders in a community. Public trust in the services rendered by community

Gerald Dapaah Gyamfi

gdgyamfi@upsamail.edu.gh

1 Business Administration Department, University of Professional Studies, Accra, Ghana 
police officers may depend on the confidence the people in that community have in the performance of police duties (Adegbile and Debo 2017).

According to Kaariainen (2008) some academic studies have been conducted in the area of exploring the trustworthiness of police by people in a community where the officers operate to ensure peace and orderliness. However, few studies have been conducted on public perception, conceptualization, and the willingness of people in a community to cooperate with the police who serve them in crime combatting in their community (Wu and Sun 2009).

Most of the studies on public trust in community policing have been carried out in the advanced world and there is an empirical gap in literature of policing and trust in many other parts of the globe. The gap is more pronounced in the developing world especially in most African countries (Gjelsvic 2020; Ordu and Nnam 2017). Even though in the advanced world community policing is progressing in diverse means, in the developing world there are a lot of problems confronting policing in communities due to skepticisms and other factors including trust and confidence (Enns 2014; Gjelsvik 2020). However, research has shown that there are some countries in the advanced world that still have some challenges with regard to intelligence-led policing philosophy and community policing (Carter and Fox 2019). For instance, in Canada, studies by Jones et al. (2019) indicate that some barriers afflicting the trust and confidence that the people have in the police include funding, infrastructure, expertise in community safety and oversight administration and peace keepers. In China, public safety, perceived political influence and effects of conflict variables affect public trust in community policing (Wu and Sun 2009).

Public opinion on the trust and confidence that the community have in the police regarding the effectiveness of community policing in the developing world triggered this researcher to explore the factors affecting public trust and the confidence that people have in community policing in developing economies such as Ghana. The author of this paper seeks to explore the perception of people on the impact of policing in their community that enable them have trust and confidence in the police service. This study is more concerned with the perception of the people in a community toward how they interpret the general attitude of the police in resolving criminal matters and other issues requiring police attention in a community (Murphy et al. 2014).

This exploratory study seeks to close the gap in literature by researching into the perception of people in a community and their trust in the effort of the police in discharging their duties as conceived. The author of this research seeks solution for the question; how do people in a community trust the policing effort to ensure peace and security in their community?

The current study is based on the problem-oriented policing (POP) conceptual framework which is a policing strategy involving the development of effective responses to crime and disorderliness in order to combat crime and maintain law in a community. POP focuses on discrete problems expected to be handled by the police in a community (Goldstein 1990). 


\section{Literature review}

In order to understand the performance of policing in a community, it is better to understand the idea of community policing and its operations. Community policing dates back to 1980s and originated from some cities in United States of America such as Los Angeles and New York (Federman 2020; Weisburd and Braga 2006). Generally, it is the expectation of community members that the police maintain peace and order and attend to broad range of criminal and trouble situations in ensuring peace and orderliness (Sitorus 2019). Other expectations of the public on community policing include ensuring equity and justice, attending to problems associated with injustices during political process and elections, illegal behaviors, racial discrimination, and other problems associated with immigration (Adegbile and Debo 2017).

The performance of police is observed through the services rendered to ensure fairness and effectiveness in attending to substantive community problems relating to crime, extortions, and other injustices (Goldstein 1990). The performance of police and how the actions are experienced by people in a community are contributing factors that determine the trust and confidence that the people have in the police. The police have the authority by law to deal with all criminal matters, both private and public and the citizenry are expected to cooperate with them by reporting culprits for police further investigation, arrests, and court action to ensure justice is executed. However, most people relent in reporting criminal acts to the police due to the perception that people have about the police service (Arisukwu et al. 2020).

\section{Influence of police encounters in communities}

The influence of police action in ensuring law enforcement and order in a society has repercussion on the trust that the people have in them (Jackson and Bradford 2009). The performance of police officers is measured by the members of a community through the rate of crime clearance. Good performance of the police is based on the community recognition of how the police deals with criminal matters as perceived by the people (Federman 2020; Kaariainen 2008). The outcome of a qualitative study of a community in Australia revealed that depending on how the police conduct themselves during an encounter between the police acting to secure the legitimacy of their operation, and the public seeking procedural justice enhance the trust that the people in the community have in the police (Schermuly 2018).

\section{Public trust based on performance outcome}

In the advanced economies such as United States of America, Australia, and the United Kingdom, research has shown that community policing has been surveyed and studied extensively using performance outcomes in the areas of crime rates, clearance rates, and traditional metrics of arrest based on perception of the program successes (Ostrom and Whitaker 1974). Studies by Schulenberg et al. (2017) 
identified the features influencing the perception that people have on police behavior to include the trust that people have in the motives of the police as encountered by the people in a community.

According to Federman (2020), Ostrom and Whitaker (1974), and Weisburd and Braga (2006) the functions expected of community police officers include developing partnership with the people in the community, solving problems, and maintenance of law and order. To guarantee public safety, community police officers are expected to engage in effective and efficient crime controls (Matvejeys 2018). Other tasks that police officers engage in during community services include having regular meetings with the people in the community and gathering information on security especially issues relating to terrorism and other crimes (Goldberg and Christopher 2019).

According to Tyler and Murphy (2011) many advanced countries, including United Kingdom, United States of America and Australia have improved the bond between the community members and the police personnel because of the cooperation between the people in the community and the police officers assigned to police the communities and this has increased the performance of the officers and raised the trust level of the people in the services that the police renders. Nevertheless, in some occasions the trust and confidence that the people in a community have for the police dwindle and wane depending on the perception of the people on how the police personnel handle certain situational factors (Murphy et al. 2014). A study in South Africa indicated that the local police officers had the perception that they practice effective community policing because they followed their standard operating procedures to contact the people in the community during their routine operations. However, the study discovered a significant level of disagreement by the people in the community with the local police officers (Makondo et al. 2021). In a related study the results proved a mistrust and discrepancy between the police and the community members in terms of the efficacy of responses to crime combat by the police (Cross et al. 2021).

\section{Proactiveness of community policing}

Community policing is an aspect of policing involving the use of proactiveness based on variety of manifestations and this has become a global phenomenon with mission driven outcomes. Structurally, community policing has been deployed using patrol modes, geographical scopes, and coordinating with external agencies (Gianakis and Davis 1998). Community policing dwells on current innovations and teambuilding as a strategy to enhance its proactiveness (Willis 2011). It involves the use of intelligence gathering that focuses on decentralized services in empowered communities. Regarding and dealing with members of the public as consumers of their services, seeking public opinion, getting feedback from informants and ensuring quality of life are other tasks expected of the community police (Weisburd and Braga 2006). The mode of operations in a community to enhance police proactiveness is expected to include foot and bicycle patrols, counseling and dealing with assigned caseloads in ensuring crime controls (Goldberg and Christopher 2019). 
Shupard and Kearns (2019) and Kaariainen (2008) reveal that lack of confidence in community policing is mostly due to poor relationship-building between the police and the community.

In Ghana, for example, according to the 1992 Constitution, article 2009 (3), the main responsibilities of Ghana Police are to ensure protection of life and properties and maintenance of law and order across all the territories of Ghana. Ghana Police Service established Community Police Unit in June 2002 with the aim of involving community residents to assist in discharging their mandated duties using means including educational talks, formation of neighborhood watch committees, sensitization through community fora and campaigns. In this study, Oyibi community is used as a case study.

\section{Brief profile of Oyibi community}

Oyibi community is a peri-urban community in the Kpone-Katamanso district of the Greater Accra region, Ghana. The community is located at a distance of about $43.9 \mathrm{~km}$ from the only international airport in Ghana (Kotoka International Airport). The community was previously occupied by $G a$ indigenes (natives of the land) who were mostly into subsistence farming and the area was poorly developed in terms of infrastructure and other amenities. In the late 1990s most people living in the city center of Accra began to acquire land from the indigenes of the area for mostly residential purposes and employed other people known as land guards to keep their lands from intruders. The land keepers were mostly illiterates, unemployed youth and masons engaged to protect the lands from encroachers since most of the new landowners were still living in the city center of Accra. The community started developing when the new landlords (land owners) started occupying their newly built houses in the community with their families. In the early 2000s the community started developing with modern amenities and infrastructure including hotels, pulps, schools, university campuses, community centers, and entertainment facilities.

The development of the land was juxtaposed with a lot of criminal activities mainly due to interspersed houses with some bushes in between some of the houses and abundance of unoccupied houses by their owners. Most of the roads leading to the residents were narrow and untarred and greater part of the places were not lit in the night. Most of the houses were, however, walled with gates. Greater part of the people left for work at the city center without any occupant in their houses during working hours until they returned from work. Few of the landlords protected their perimeters with well trained dogs and majority of them left their houses without any guard. Just a few of the houses had security cameras.

Due to the high crime rate in the community, the residents of the community formed Oyibi Residents Association with the main aim of protecting their community from criminals. With high communal spirit the association put up a police post. According to Ghana News Agency (2005), the Oyibi Police Post was commissioned in 2005 by Ghana's Deputy Commissioner of Police, Mrs. Elizabeth Robertson who commended the residents for their communal spirit and in attendance was the then Deputy Minister of Interior. 


\section{Criminal activities at Oyibi community}

It was the expectation of the community that with the establishment of police post criminal activities in that community would be curbed. However, due to the alarming rate of crime in the community most of the community members were still living in fear. Many research and mass media report on the community indicated that the crime rate had risen due to lack of logistical support for policing in that community. For instance, Darkwah and Attorquayefio (2012) reported that on September 24, 2010, land guards subjected the residents to brutal attacks with many casualties. According to Syme (2018), in February, 2018, alone, the residents reported of 16 different robberies with two people residing in the community short dead during the attacks. There were reports of injustices, human right abuses and corrupt practices that the residents experienced without any police intervention (Darkwah and Attorquayefio 2012).

\section{Methods}

This study seeks to explore the factors affecting public trust in police service rendered at a community. This researcher scrutinized the three approaches; quantitative, qualitative and mixed methods for suitability based on the nature of the study. The expectation of subjective feeling and exploratory nature of the study compelled this researcher to use qualitative case study for this study. This method of the study is suitable because it seeks the views of people in a community on their trust in the services rendered by the police in their community (Curtis and Fossey 2007). In selecting qualitative approach, the study realized that the approach provides a useful guide for research into the perception of people based on their subjective judgements. The approach also serves a useful purpose for the researcher in terms of the approach for data collection, reliability and validity, ethical norms, and data analysis as prescribed by Merriam (2009), Bogdan and Biklen (2007).

According to Merriam (2009), case studies provide detailed analysis of a phenomenon that a researcher intends to make provision for a logical means for ascertaining the truth. Exploratory nature of this study intends to seek views from community members on their trust in police that they will get police protection based on the provision of the law on the security and safety of people in that jurisdiction (Gyamfi 2020; O'Rourke and Macey 2003). This approach provides in-depth description of the feelings of people in a community on how they trust the attitude of police toward their security, protection, and their feeling of justice and freedom from threat in that community (O'Rourke and Somerville 2009).

This researcher used qualitative case study because the aim of exploring public trust in a community policing, as envisaged by this study, was to capture the participants experiences as grounded in their cognition of policing in their community and the trust that they had in the services rendered to secure their safety as residents of that community. The author of this paper took into consideration the criticism of subjective bias nature of qualitative studies due to personal inclinations and other confounds or threats (William 2010). To overcome this threat, this researcher 
used internal consistency and other reduction approaches to enhance vivid and thick rich description of this exploratory study (Oliver 2006; Van der Spuy 2009). Another challenge associated with qualitative studies is based on how to generalize the outcome of the studies beyond the sample and population used for the studies. To overcome this challenge, this researcher used rigor and triangulation to ascertain the real-world view that can translate the result to other similar situations and make the outcome of this study to become very high in comparative international studies (Chenail 2010). The researcher also tried to reduce confounds that could affect the generalization of this research through bracketing. This author also established rapport building with the participants for the establishment of pathways that could link the study and the questions relating to policing and public trust (Gouard 2017).

This study covers the people in Oyibi community which is in Kpong Kantamanso district of the Greater Accra region of Ghana. The population of that community as provided by Ghana Statistical Service during the last census of Ghana in 2010 was 109,864 made up of 48.6 percent males and 51.4 percent females. In this study, 120 participants were drawn from the community using convenience sampling technique. The participants were people regarded as heads of various households. A household head is defined by this study as an occupant of a house in that community recognized by all the other household members as the head or landlord of the house with social responsibility for all the occupants of that house. Due to the dispersed nature of the houses in that community, this study selected the houses from every part of the community.

\section{Data collection}

The author used one-on-one interview, triangulated with field notes and focus group discussion, for the data collection. Prior to the interview, the study sought the consent of the participants, after explaining the reason for the interview with them and compelled each one of them to sign two consent forms indicating their willingness to become partakers of the study at their own freewill. The author of this paper kept a copy each of the signed consented form and the subjects also kept their copies before they became participants of this study. The researcher disclosed to the participants their right to opt out anytime they perceived their right had been trampled upon and assured them of the confidentiality of their identities as participants of the study. The interview took place at convenient locations of the participants. The participants consented to confirm the recorded interview, after transcription, during the member-checking process in order to eradicate or reduce researcher subjectivity bias during the study.

\section{Instrumentation}

This researcher designed the instrument for the study after realizing that there was no available well designed and tested instrument for a qualitative study exploring public trust in policing at a community that is developing from peri-urban to urban and its associated risk. In designing the instrument, the research question 
served as a guide in determining the initiating questions for the interview with the expectation that there would be follow-up questions through induction (Pereira 2012). The instrument comprised twelve initiating questions including initial grand tour questions to induce the participants to come out with open-ended answers regarding their perception of policing in their community. The interview grand tour questions included; "Please tell me about your experience with policing in your community?" Other questions for the study were: "Kindly tell me more about the trust you have in your community policing?" "Please, share your experience with me on the trust that you have in how the police handle your security," "Can you tell me about your views on the security situation at your community?" The questions that this researcher asked to enable the participants to explore their own thoughts included: "Describe your feelings on how the police maintain peace and order in your community," and "What is your understanding of community policing?

The Researcher ensured reliability of the instrument by engaging a four-member panel of experts to review the instrument and check how relevant the questions could induce the participants to contribute toward the achievement of results. The panel also made a lot of contributions to the validation of the proposed initiating interview questions. The instrument was also subjected to a field test by ten other subjects in the community to check the appropriateness of the words used and the participants understanding of the questions (Curtis and Fossey 2007).

The author is a faculty member of a university that has a research committee (equivalent to IRB) that seeks to review academic papers through a forum where other faculty members critique the paper especially in terms of how the paper meets all ethical considerations prior to submission for publication. This paper was approved by the committee after the review.

\section{The Interviews}

At the onset of the interview, in order to hide the identities of the participants, the interviewer gave every interviewee a three-digital code representing the first letter of their surnames to signify their identities. The interviewer craved the indulgence of the participants to record the interview and urged them to freely contribute their views without any fear or favor with the intention of creating a flexible environment for the study. The researcher assured the confidentiality of the interview and gave the participants the right to opt out if they perceived any infringement on their rights. Every interview took about one hour during a day. The interview took place in October 2020, after the government of Ghana had eased the restrictions of movement of people due to the spread of Covid-19 pandemic. The main observer took field notes of the body language of the interviewees during the one-on-one interview for the sake of triangulation to enrich the reliability of the study. After the one-onone interview, in order to reach data saturation, three focus group discussion took place. Every focus group comprised five participants. In all 120 participants contributed their views during the data collection phase of the study. 


\section{Data Analysis}

The respondents' demographic characteristics are as demonstrated in Table 1. Majority of the respondents were males (79\%). The predominant age group was between 40 and 60 years old and majority of them had educational qualifications below undergraduate level. The predominant tribes of the respondents were Gas and Akans.

The observer transcribed the audio-recorded data into text and obtained confirmation and approval of the transcribed data from the various participants as a means of member-checking. Data analysis continued after coding the text messages, field notes from observation of body language, and notes made from the literature review, using deductive and logic means (Creswell 2005). During the coding process, this author represented the essence of the data gathered with words or phrases. The author continued the data analysis using qualitative software, NVivo, after importing the coded data into the software. The software aided the coding process by creating nodes and highlighting the various text messages with commonalities (Bazeley and Jackson 2013). According to Zamawe (2015), NVivo software aids researchers to make deep analysis through the arrangement of coded data and concepts into trends, nodes. The software also aided the generation of sub-themes through reiterative approach using "see also" links. In this current study, through the creation of commonalities and nodes the software aided the generation of the following sub-themes: fear of reprisals, lack of confidence, and police presence.

Table 1 Respondents demographic characteristics

\begin{tabular}{lcl}
\hline Variable & Frequency & Percentage \\
\hline Gender & & \\
Male & 95 & 79 \\
Female & 25 & 21 \\
Age & & \\
Below 30 & 5 & 4.2 \\
$30-39$ & 15 & 12.5 \\
$40-49$ & 40 & 33.3 \\
50-59 & 35 & 29.2 \\
Above 60 & 25 & 20.8 \\
Education & & \\
Up to Diploma & 75 & 62.5 \\
Undergraduate & 30 & 25 \\
Graduate & 15 & 12.5 \\
Ethnocultural Identity & & \\
Ga & 41 & 34.2 \\
Akan & 39 & 32.5 \\
Ewe & 25 & 20.8 \\
Others & 15 & 12.5 \\
\hline
\end{tabular}




\section{Thematic Analysis}

Using deductive logic means based on categorization of the data context, the following themes resonated: Fear of reprisals from criminals, lack of confidence in policing at the community, and poor police presence in the community.

\section{Theme 1: Fear of Reprisals from Criminals}

Majority of the participants indicated that they do not trust the community police because the police officers were not trustworthy. According to them some criminals they arrested and sent to the police for court action and justice to prevail were soon released. The purported criminals started attacking the accusers for their involvement in sending them to the police. A participant disclosed with a high tone, "After reporting two thieves to the police, I was expecting that the police would pursue the case further by secretly inviting me to give account of my version at the court as a witness but this did not happen." Another participant said her trust in the police personnel at the community was very low that she decided not to report any criminal to the police at their station because she perceived that most of the criminals had some acquaintances with the police. According to her, the thieves who were arrested by the police, based on her report to the police, later on came back to physically attack her for reporting her to the police. About 19 percent of the participants were wondering whether there was police presence in Oyibi community to protect the people culpable of becoming victims of crimes there. The participants were of the view that some of the criminals compromised with the police and therefore reporting their cases would tantamount to nothing. This perception made them conceive that they might suffer some consequences from the purported criminals. Nevertheless, six percent of the participants expressed their happiness with how the police based their arrest on the information supplied without any reprisals.

\section{Theme 2: Lack of Confidence in Policing at the Community}

Almost all the participants expressed their lack of confidence in policing at the community. A female participant asked a question, "do we have people policing our community?" This question was based on her accounts of the number of times people in that area had been attacked and afflicted by armed robbers without the police coming to their rescue. Four participants disclosed that some thieves broke into their houses and stole some items and also destroyed their luggage without getting any help from the police after making some distress calls. According to them when they reported to the police, initially, police officers were assigned to inspect the places of attack but after the first visit the police did not take any further action even though they kept on going to the police station to find out about the outcome of the police investigation. Some of the participants also reported on how some assailants using motorbikes snatched their bags and other belongings in the community during both night and day and doubted what the police was doing to curb the menace. During the focus group discussion members of the three groups agreed and pointed to some places where a gang of people used to meet as their ghettos where they used 
to smoke marijuana and other drugs both day and night without hiding but the police was adamant. A participant disclosed that one of his tenants reported to him, "I saw one of the wee smokers there who slashed one of their colleagues with a sharped knife and the victim was bleeding." According to majority of the interviewees such attacks were rampant in the community but there were no police action.

\section{Theme 3: Poor Police Visibility in the Community}

Poor police visibility in the community was another factor that almost all the participants agreed it was a major problem to them. A male participant asked a question, "do we really have police station at our community?" One of the focus group participants agreed that the house owners formed Oyibi Residence Association based on lack of police visibility in the community. Out of the association emanated Oyibi community watch group which used to patrol the area during the night to defend their community from criminals. A few of the participants, however, were of the view that during the night whenever there was suspicion of armed robbers attack and they called the national police patrol telephone numbers there were some responses and police presence with their siren alarms. This reaction of the police resulted from the media heightening and after prolonged complaints of armed robbers in the area. One of the focus group interviewees also agreed to the occasional police alarms since 2018. Eighty-five percent of the interviewees had negative perception and mistrust in how the police combat crime in the area.

\section{Discussion}

This study seeks to explore public trust in community policing using a community in Ghana. The study is based on the conceptual framework of problem-oriented policing with emphasis on dealing with problems associated with security of people in a community. The thematic analysis revealed that the public trust in policing effort to secure peace at the community was not encouraging. Based on the exploratory study, the people in the community lack trust in the police based mainly on fear of reprisals from criminals, lack of confidence in the policing effort, and poor police visibility. The lack of trust may be due to the poor relationship-building between the police and the people in that community as revealed from the outcome of a study by Shupard and Kearns (2019). Majority of the respondents were of the view that lack of trust in the community policing was based on fear of crime and poor police responses. This outcome is in congruent with the findings of a similar study in Canada by Jones et al. (2019), China by Wu and Sun (2009), and in Finland by Kaariainen (2008).

The outcome of this study also reveals that the people in the neighborhood lack trust in the community policing based on perception that the police would leak the informants' identity that could lead to the informants rather becoming victims and suffer reprisal attacks from the purported criminals. This outcome may be due to past experiences of the respondents where they were victimized by assailants after informing the police of their experiences with the purported criminals. 
Police conduct, when they have encounter with people in a community has tremendous effect on the trust that the people have in community policing as proved by the research findings of Schermuly (2018). This finding is similar to that of a prior research demonstrating a relationship between trust and public satisfaction with the police by Jones et al. (2019), Kaariainen (2008).

Poor police visibility is another factor revealed by this study as a contributory factor to the lack of trust in policing at the community. Considering the nature of the community where some houses are sparsely located with bushes in between some of the houses, the people might harbor fear resulting from criminals using the bushes as safe havens to perpetuate their criminal activities. In this situation police visibility in the community could ease their perception of mistrust but according to majority of the respondents the police presence in their neighborhood was very poor. This could result from lack of logistics and police personnel at the community police post. To increase the trust and confidence in the police there must be a reform that could enhance the police visibility and technology in the community as resulted from Gjelsvik (2020) in Kenya. A few of the participants in this study disclosed that the National Police Patrol team was available to rescue them when they made distress call using the available national police telephone lines and this could have resulted from their mistrust in the community police.

Even though the outcome of this study relates positively to similar studies carried out in China and many other parts of the world that public trust in police is based on factors including police visibility, community perception of police poor handling of criminal cases leading to lack of confidence in policing and poor handling or keeping of confidentiality of informants leading to reprisals (Schermuly 2018; Wu and Sun 2009). However, generalization of the outcome of this study should be with caution because of its qualitative nature and its limitation to only one community in Ghana (William 2010). It is expedient for other future researchers to also focus on factors relating to satisfaction of performance of community policing, using quantitative approach. The future study could be either from the perspective of police officers or the people in a community. The outcome of this study provides a lesson that government's attention on developing peri-urban communities should focus mostly on enhancing the policing effort to combat crime and other duties through community policing with problem-oriented policing philosophy guidance.

\section{Conclusion}

This exploratory paper was to seek the perception of a community on the trust that the people have in policing at their community. The research question was, "how do people in a community trust the policing effort to ensure peace and security?" The study was based on the concept of problem-oriented policing with emphasis on police effort to handle discrete problems associated with a community. The researcher used qualitative case study in the exploratory process. The thematic analysis revealed that fear of reprisals from criminals based on police officers disclosing the identities of informants, poor police visibility, and lack of confidence resulting from increasing criminal activities were the major factors that aggravated the lack of 
public trust in community policing at the Oyibi community. The study recommends that future research in this area should focus on quantitative studies on factors relating to public satisfaction and community policing. The outcome of this study also gives the implication that due to urban drift, security at developing peri-urban communities using community policing should be enhanced to curb criminal activities that usually accompany the development.

\section{Declarations}

Conflict of interest On behalf of all the authors, the corresponding author states that there is no conflict of interest.

\section{References}

Adegbile, D.P., and P. Debo. 2017. Policing through an American prism. Yale Law Journal 126 (7): 2222-2259.

Arisukwu, O., C.J. Igbolekwu, E.S. Oyeyipo, F. Asamu, B. Rasak, and J. Oyekola. 2020. Community participation in crime prevention and control in rural Nigeria. Heliyon 6 (9): e05015.

Bazeley, P., and K. Jackson. 2013. Qualitative data analysis with NVivo. London: Sage.

Bogdan, R.C., and S.K. Biklen. 2007. Qualitative research for education: An introduction to theories and methods, 5th ed. Boston, MA: Pearson A \& B.

Carter, J.G., and B. Fox. 2019. Community policing and intelligence-led policing: An examination of discriminant validity. Policing: an International Journal 42 (1): 43-58.

Chenail, R.J. 2010. Getting specific about qualitative research generalizability. Journal of Ethnographic Qualitative Research 5 (1): 1-11.

Creswell, J.W. 2005. Education research: Planning, conducting, and evaluating quantitative and qualitative research. Thousand Oak, CA: Sage Publication.

Cross, C., T. Holt, A. Powell, and M. Wilson. 2021. Responding to cybercrime: Results of a comparison between community and police personnel. Trends in Crime \& Crime Justice 635: 1-20.

Curtis, M., and E. Fossey. 2007. Appraising the trustworthiness of qualitative studies: Guidelines for occupational therapists. Australian Occupational Therapy Journal 54 (2): 88-94.

Darkwah, L., and P. Attoquayefio. 2012. Land guards, state subordination and human rights in Ghana. International Journal of Human Rights 17: 1-18.

Enns, P.K. 2014. The public's increasing punitiveness and its influence on main incarceration in the United States of America. Journal of Political Science 58 (4): 857-872.

Federman, P.S. 2020. Police performance as symbolic politics? Public recognition and the value of awards. Performance of Management Review 43 (2): 363-387.

Ghana News Agency. 2005. New police post for Oyibi. Retrieved from www.ghanaweb.com/Ghana HomePage/NewArchive/New-police-post-for-oyibi-92118

Gianakis, G.A., and G.J. Davis. 1998. Reinventing or repackaging public services? The case of community-oriented policing. Public Administration Review 58 (6): 485-498.

Gjelsvic, I.M. 2020. Police reforms and community policing in Kenya: The bumpy road from policy to practice. Journal of Human Security 16 (2): 19-30.

Goldberg, K., and K. Christopher. 2019. Community oriented policing: Security in the domestic counter terrorism environment. Journal of Business \& Behavioral Sciences 31 (1): 114-124.

Goldstein, H. 1990. Problem-oriental policing. New York, NY: McGraw-Hill Inc.

Gouard, R. 2017. Public engagement for police departments: How to build and regain trust. Public Management 99 (6): 26.

Gjelsvik, I.M. 2020. Police reform and community policing in Kenya: The bumpy road from policy to practice. Journal of Human Security 16 (2): 19-30.

Gyamfi, G.D. 2020. Exploring the roles of police leaders in countries in transition. International Journal of Rik and Contingency Management 9 (4): 1-17. 
Jackson, J., and B. Bradford. 2009. Crime, policing and social order: On the expressive nature of public confidence in policing. The British Journal of Sociology 60: 493-521.

Jones, N.A., R. Ruddell, and T. Summerfield. 2019. Community policing: Perception of officers policing indigenous communities. Canadian Journal of Criminal Justice 61 (4): 41-65.

Kaariainen, J. 2008. Why do the Finns trust the police? Journal of Scandinavian Studies in Criminology \& Crime Prevention 9 (2): 141-159.

Makondo, S.S., J.T. Mafokeng, and D. Khosa. 2021. Perspectives on community policing forums in rural areas of Limpopo Province in South Africa. International Journal of Criminal Justice Sciences 16 (1): 161-185.

Matvejeys, A. 2018. Effective crime control as guarantor of public security. Journal of Security \& Sustainability Issues 7 (3): 417-426.

Merriam, S.B. 2009. Qualitative research: A guide to design and implementation. San Francisco, CA: Jossey-Bass.

Murphy, K., L. Mazerolle, and S. Bennett. 2014. Promoting trust in police: Findings from a randomized experimental field trial of procedural justice policing. Policing and Society 24 (4): 404-425.

Oliver, P. 2006. Purposive sampling. In The SAGE dictionary of social research methods, ed. V. Jupp, 245-246. London: SAGE.

Ordu, G.E., and M.U. Nnam. 2017. Community policing in Nigeria: A critical analysis of current developments. International Journal of Criminal Justice 12 (1): 83-97.

O'Rourke, D., and G.P. Macey. 2003. Community environmental policing: Assessing new strategies of public participation in environmental Regulation. Journal of Policy Analysis \& Management. 22 (3): 383-414.

Ostrom, E., and G. Whitaker. 1974. Community control and governmental responsiveness: The case of police in black neighborhood. Washington, DC: National Criminal Justice.

Pereira, H. 2012. Rigor in phenomenological research: Reflections of a novice nurse researcher. Nurse Researcher 19 (3): 16-19.

Schulenberg, J.L., A. Chenier, S. Buffone, and C. Wojciechowski. 2017. An application of procedural justice to stakeholder perspectives: Examining police legitimacy and public trust in police complaints systems. Policing and Society 27 (7): 776-796.

Schermuly, A.C. 2018. Encounter between the police and the public: Seize the day or practice avoidance? Journal of Criminological Research, Policy \& Practice 4 (2): 148-160.

Shupard, M., and E.M. Kearns. 2019. Why do officers support community policing? A cross-departmental and cross-temporal comparison. Behavioral Science \& the Law 37 (6): 665-680.

Sitorus, T. 2019. Extortion operation and police members performance and its impact towards public trust. Academic Journal of Economic Studies 5 (4): 52-61.

Somerville, P. 2009. Understanding community policing. Policing: an International Journal of Police Strategies \& Management 32 (2): 261-277.

Syme, S. (2018). Oyibi residents live in fear. Graphic Online. Retrieved from www.graphic.com.gh/ oyibi-residents-live-in-fear-as-residents-as-armed-robbers-have-field-day

Van der Spuy, E. 2009. Police cooperation in the Southern African region: Politics and practicalities. Crime, Law, and Social Change 51 (2): 243-259.

Weisburd, D., and A.A. Braga. 2006. Police innovation: Contrasting perspective. Cambridge, UK: Cambridge University Press.

William, A. 2010. The importance of distinguishing between the theoretical attitude and the natural scientific attitude in the discipline of psychology. Studia Phenomenologica 10: 235-250.

Willis, J.J. 2011. Enhancing police legitimacy by integrating compstat and community policing. Policing: an International Journal of Police Strategies \& Management 34 (4): 664-673.

Wu, Y., and I.Y. Sun. 2009. Citizen trust in police: The case of China. Police Quarterly 12: 170-191.

Tyler, T.R., and K. Murphy. 2011. Procedural justice legitimacy and cooperation with the police: A new paradigm for policing. Brisbane: Griffith University.

Zamawe, F.C. 2015. The implication of using NVivo software in qualitative analysis: Evidence-based reflection. Malawi Medical Journal 27 (2): 13-15.

Publisher's Note Springer Nature remains neutral with regard to jurisdictional claims in published maps and institutional affiliations. 